\title{
Self-Knowledge, Elenchus and Authority in Early Plato
}

\author{
Fiona Leigh \\ University College, London \\ fiona.leigh@ucl.ac.uk
}

\begin{abstract}
In some of Plato's early dialogues we find a concern with correctly ascertaining the contents of a particular kind of one's own psychological states, cognitive states. Indeed, one of the achievements of the elenctic method is to facilitate cognitive selfknowledge. In the Alcibiades, moreover, Plato interprets the Delphic injunction, 'know yourself', as crucially requiring cognitive self-knowledge, and ending in knowing oneself as subject to particular epistemic norms. Epistemic authority for self-knowledge is, for Plato, conferred on the basis of correct application of norms to cognitive selfascriptions, and not confined to the first-personal perspective. This implies firstpersonal plural epistemic authority for self-knowledge.
\end{abstract}

\section{Keywords}

self-knowledge - elenchus - epistemic authority - dialogue - Alcibiades - Apology Laches - Gorgias

\section{Introduction}

In contemporary discussions of the topic that has become known as 'selfknowledge', philosophers not infrequently ask whether knowing the contents of one's own thought is like perception or something more distinctive and special, or worry about privileged access to one's own states. ${ }^{1}$ By contrast, scholarly

1 See for example, Ryle 1949, ch. 6, Evans 1982, Boghossian 1989, Shoemaker 1994, Cassam 1994, O’Brien 2007, Gertler 2015 . 
investigation into self-knowledge in ancient thought has in large part focused on interest in knowing things about oneself, most importantly the state of one's moral character, so that self-knowledge becomes, in effect, a moral imperative. ${ }^{2}$ The contrast is nicely, if somewhat facetiously, captured by Quassim Cassam, who writes: 'Only a philosopher would think of calling my knowledge that I believe that I am wearing a pair of socks "self-knowledge"; it's certainly far removed from anything that the ancients ... would recognize as self-knowledge. ${ }^{3}$ In this paper, I will argue for a conception of self-knowledge in some of Plato's early dialogues - the Apology, Alcibiades, Laches and Gorgias - that in important respects undermines the dissonance thought to characterise the respective objects of self-knowledge for ancient and contemporary philosophers. In these dialogues, we find evidence for a concern with correctly ascertaining the contents of, and in that sense arriving at knowledge about, a particular group of one's own psychological states, which I shall call cognitive states. Cognitive states are those the agent takes to be truth-apt, states she describes for example as beliefs or opinions, how things seem (seemings), appearances or states of knowing. One of the achievements of the elenctic method as found in these dialogues is to facilitate cognitive self-knowledge-or so I will argue.

In addition, I will maintain that in the Alcibiades we can read Plato as selfconsciously interpreting the Delphic injunction to 'know yourself' in such a way that obeying its command crucially requires cognitive self-knowledge, and ends in comprehension of oneself as inherently rational and subject to rational norms. If this is right, Plato's own conception of self-knowledge, 'Platonic self-knowledge', and the goal of his elenctic method both have cognitive selfknowledge at their core: Platonic self-knowledge is in large part constituted by cognitive self-knowledge, understood as correctly ascertaining what one really thinks. It is distinctively self-knowledge in virtue not only of clarifying the content of one's own cognitive states but also by doing so oneself, by way of the active and self-conscious exercise of one's own capacity for reason.

In the first two sections of the paper I attempt to establish this reading. In Section 2, I examine passages from the relevant dialogues and argue that cognitive self-knowledge is on display. I then turn in Section 3 to Plato's own conception of self-knowledge in the Alcibiades and offer a reading of it as consisting in cognitive self-knowledge and knowledge of ourselves as inherently rational. Since the reading proposed goes against the orthodox reading of the eye-soul analogy at the end of the Alcibiades (according to which the soul is

2 Prominent examples include Griswald 1983, Annas 1985, Rappe 1996, Sherman 1997, Remes 2013, Kamtekar 2017, Renz 2017. See also McCabe 2015.

3 Cassam 2014, 28. 
somehow reflective), I begin Section 3 with an argument against that reading. In Section 4, I will suggest that on the reading proposed epistemic authority for self-knowledge is not, for Plato, conferred simply on the basis of occupying the first-personal viewpoint, but on the basis of applying epistemic norms in such a way that makes room for the views and authority of others through dialogue. This in turn implies first-personal plural epistemic authority as regards self-knowledge.

\section{Cognitive Self-Knowledge in the Apology, Alcibiades, Laches and Gorgias}

\subsection{The Apology and the Alcibiades}

The figure at the heart of what I have called cognitive self-knowledge in the early dialogues is Socrates, in two respects: Plato depicts Socrates as himself having cognitive self-knowledge-i.e. having a correct estimation of the content of the cognitive states of his own soul-and as the practitioner of the method that facilitates his own and others' arrival at cognitive self-knowledge. Socrates gives an account of his cognitive self-knowledge and of the method, often referred to in the scholarship as the elenctic method, in the Apology.

In his defence speech, Socrates asserts that care of one's own soul (heautou epimeleisthai) consists in ensuring it is as good and wise as possible $\left(36 \mathrm{c}_{3}-8\right),{ }^{4}$ and that this greatest of benefits consists in discussing virtue and testing oneself and others, and thereby living an examined life (38a1-7). ${ }^{5}$ Socrates' life has in this way been an examined one, and evidently one result of his examinations is that he has a distinctively cognitive kind of self-knowledge: he declares not only that he does not know (e.g. what the virtues are), but also that he does not think that he knows (21d2-8). ${ }^{6}$ This awareness is, it seems, a direct result of

4 Apol. 36c3-8: 'but I went to each of you privately and conferred upon him what I say is the greatest benefit, by trying to persuade him not to care ( $\dot{\varepsilon} \pi \mu \varepsilon \lambda \varepsilon \hat{\sigma} \sigma \theta \alpha)$ for any of his belongings before caring ( $\dot{\varepsilon} \pi \mu \varepsilon \lambda \eta \theta \varepsilon i \eta)$ that he himself should be as good and as wise as possible' (tr. Grube). Cf. 29e, 3ob, 3ib.

5 Apol. 38a1-7: 'On the other hand, if I say that it is the greatest good for a man to discuss virtue every day and those other things about which you hear me conversing and testing myself and others, for the unexamined life is not worth living for men, you will believe me even less' (tr. Grube).

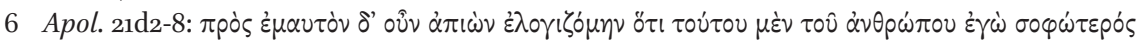

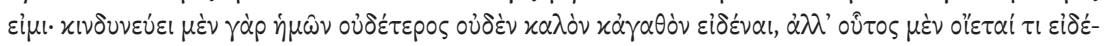

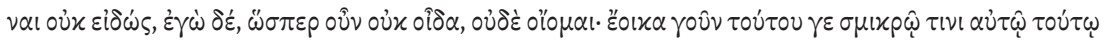

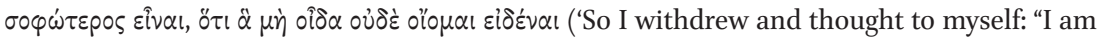
wiser than this man; it is likely that neither of us knows anything worthwhile, but he thinks 
devoting his time to examining each matter, which examination is depicted in the dialogues as taking place by way of critical conversation, with whomever he is able, whenever he is able. ${ }^{7}$ Care of one's own soul requires, or consists in, cross-examination as practised by Socrates - the elenctic method. ${ }^{8}$ And although the practice proved costly to him, Socrates suggests in the Apology that his aim is to bring about this self-care in his fellow Athenians by subjecting them to cross-examination $\left(36 c_{3}-8\right)$. I want to suggest that one of the central aims of the elenctic method in the dialogues that we will consult from the early period - the Alcibiades, Laches and Gorgias - is to allow his interlocutors to arrive at cognitive self-knowledge too, in that like Socrates they come to ascertain correctly the contents of, and so come to a correct estimation of, their own cognitive states.

The topic of the Alcibiades is the future success and flourishing of Alcibiades himself, a topic of such importance to the much-fêted young man that he is willing to converse with Socrates on its promise alone. ${ }^{9}$ Socrates' questions target cognitive states (beliefs, and states that Alcibiades takes to be knowledge) that Alcibiades attributes to himself on the topic of justice and international affairs, with the result that Alcibiades ends up doubting the content of his beliefs and repudiating his claims to knowledge. For instance, at 106c-1ogd, although he considers himself to have knowledge on these matters, indeed to know better than the Athenians, it turns out that he cannot say what it is for

he knows something when he does not, whereas when I do not know, neither do I think I know; so I am likely to be wiser than him to this small extent, that I do not think I know what I do not know"': tr. Grube). Cf. 22c, $22 \mathrm{e}$.

7 Doyle 2012 has argued that Socrates knows himself to lack knowledge prior to embarking on the project of cross-examining others and cites 23a5-b4 (2012, 43-4). But here Socrates could mean merely that he embarked on the project of confirming to himself that the Oracle was wrong to imply that he possessed the wisdom of someone who knows, which project required a large-scale effort of consulting the claims of others to know very widely. If so, then the text is consistent with the suggestion that, since Socrates always understood that his 'human' wisdom was worthless, and has long been concerned with truth and wisdom, and the care of his soul (23b, 32e-33b, 36b-d, $38 \mathrm{a}$; cf. implicitly $29 \mathrm{~d}-3 \mathrm{oc}$ ), he has similarly long been engaged in cross-examination of his own thoughts, and that of those he cares for, his friends, in conversation.

8 The precise details of the elenctic method have been much disputed. Here, it is sufficient for my purposes to adopt a minimalist—and so, I hope, uncontroversial—conception of the method: an interlocutor makes a claim, usually (but not always) a substantive or definitional claim about one of the moral virtues; Socrates, or the questioner, then secures the interlocutor's agreement to further claims which taken together contradict the original claim.

9 I take it that Nicholas Denyer has shown that the arguments against attributing the dialogue to Plato are less than compelling (2001, 14-26; cf. Annas 1985, 112-15 and Jirsa 2009. For a recent expression of doubt, see Smith 2004). 
a city to act correctly or to do the better thing in relation to war and peace (108d ff.). And at 109d-11oe he asserts that he knows what justice and injustice are, yet he cannot give an account of how he learned it, from whom, and at what prior point he realized that he did not in fact know it (noc-d), and he does not say what justice consists in.

At 112d, when Socrates asks whether it has turned out on the basis of their conversation that Alcibiades in fact has knowledge (eidenai, $\mathrm{d} 7$ ) of justice and injustice, Alcibiades says that it is not very likely 'from what you say'. And here, significantly, Socrates makes a great deal of fuss, insisting at some length and with the aid of several examples from 112e-113b that it is Alcibiades who is making various claims, not him. At $113 \mathrm{~b}-\mathrm{c}$ he again repeats that the statement that Alcibiades lacks knowledge of justice and injustice is not something he, Socrates, says, but what Alcibiades himself is saying (113b5-c1; tr. Hutchinson):

Soc.: Well, then, which of us said what was said?

Alc.: From what we've agreed, Socrates, it seems that I did.

Soc.: And what was said was that Alcibiades, the handsome son of Clinias, doesn't understand justice and injustice- though he thinks he doesand that he is about to go to the Assembly to advise the Athenians on what he doesn't know anything about. Wasn't that it?

Alc.: Apparently.

Socrates' point is that it is Alcibiades himself who comes to this higher-order view, a view about his own first order states. Socrates then goes on to persuade Alcibiades of the belief that the just is always advantageous and never disadvantageous. But Socrates' method of persuasion is not to convince Alcibiades to accept some view of Socrates' own, on Socrates' authority. Instead, he suggests that Alcibiades would be most convinced of a claim if it is one he arrives at himself, and is aware of arriving at it himself, telling him: 'If you don't hear yourself say that just things are also advantageous, then don't believe anything else I say' (114e-7-9). As before, he extracts this opinion from Alcibiades on the basis of its being entailed by a series of other beliefs that he, Alcibiades, appears to hold already, prior to his questioning by Socrates. Some of these prior beliefs, for example, are that courage is valued as good by its possessor, that it is good insofar as it involves doing good things and is admirable because of this, and that it is problematic to say that something is good and bad in the same respect (115d-116a). ${ }^{10}$ Moreover the truth of these previously held beliefs

10 This last is not explicitly stated in the text. It must, however, be read as implied by (a) Alcibiades' (surely uncomfortable) admission to the conclusion that, in saying that 
is something that, upon reflection, Alcibiades either regards as certain or as clear: he is certain that he values courage as a good (115d-e: he would rather die than be deprived of it), and it seems clear to him that saving one's friends in battle is admirable because it is an act of something good, courage (115e). The inferential connections between these beliefs and the conclusion that nothing admirable insofar as it is admirable is bad are, on the most sympathetic reading, valid. ${ }^{11}$ And last, the inconsistency between this conclusion and his previous supposition at 115 a that some admirable things are bad is made apparent to him: at the end of the passage, at 116e, Alcibiades declares himself bewildered, saying that he first thinks one thing and then another. When Socrates diagnoses his state as one of wavering (planasthai, 117a1o; cf. 112d, 116d-e) between conflicting beliefs, a state brought about by not knowing but thinking oneself to know, Alcibiades once more agrees.

Throughout this cross-examination by Socrates, Alcibiades' critical gaze is not only steered by Socrates towards the objective matters mentioned in the discussion, e.g. what justice is, but also towards his other pre-existing or background beliefs and knowledge-claims relevant to such matters. He is directed to clarify their content, and to consider what follows from them. Concerning these objective issues, progress in a negative sense is made concerning Alcibiades' first-order beliefs, insofar as some of them become less compelling to him. Positive progress is also made, since other beliefs about justice (e.g. that it is always advantageous), which he has ground to take to be true, come to light. I take it that, since such freshly articulated beliefs follow from what Alcibiades apparently thought in advance of Socrates' questioning, rather than

rescuing one's friends in battle is admirable but bad, he meant exactly the same as if he had called it good but bad (116a6-9), together with (b) Socrates' further conclusion that 'nothing admirable, to the extent that it is admirable, is bad, and nothing disgraceful to the extent that it is disgraceful, is good' (116a1o-11). (Except where stated otherwise, translations of the Greek are my own.)

11 Contra Denyer 2001, 147-8 who, although he seems to regard the reasoning in this passage (from 115a-116a) as on the whole valid, finds that of 115e9-11 problematic. The trouble, he thinks, is that from the claims that courage is admirable (115a-b) and that courage is good $(115 \mathrm{c}-\mathrm{e})$ it does not follow that it is admirable because, or insofar as, it is good. We can see that Socrates' reasoning is defensible, however, by first noting that Plato has Socrates

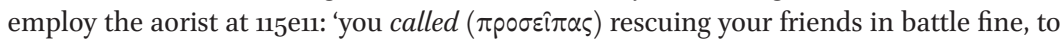
the extent that it is fine, in that it is an act of a good thing, namely courage' (115e9-11). This clearly looks back to $115^{b} 5^{-7}$, where Alcibiades agreed to Socrates' clarification of his (i.e. Alcibiades') view of courage as a fine thing: 'So you call a rescue of this sort fine, in that it is an attempt to save those it is necessary to save, and this is courage—right?' So it was Alcibiades' belief all along that courage is fine insofar as it is doing something, e.g. rescuing loved ones, where he (all along) understands such actions to be good. 
from new information or from the acquisition of a new piece of knowledge, they are for Plato in an important sense first-order beliefs he already had.

But, in addition - and significantly for my purposes-Plato takes care to show Alcibiades also being led to self-consciously examine and form wellreasoned, i.e. valid, higher-order judgements about his own first-order beliefs and what they entail. He first learns that he holds a set of beliefs the truthvalue of which, upon reflection, he decides is warranted. He also learns that these beliefs, properly clarified, on their own entail the belief that justice is always advantageous, and so that he has well-grounded reasons, and in a significant sense always did have such reasons, to endorse this belief as his own. ${ }^{12}$ From this he also learns that, even though he previously self-consciously avowed the opposite as his belief, in the absence of strong reasons or evidence in favour of this opposite belief, and in light of solid reasons for the newly revealed belief, he in fact has reason to give up that previously avowed belief. Finally, from these he learns that although he declared himself knowledgeable about justice, he now has reason for the view, which he endorses, that he is not knowledgeable on the subject, but ignorant. ${ }^{13}$ In guiding his thinking this way, Socrates has led him to follow a number of epistemic norms, standards by which he can come to a correct estimation of his own beliefs, and of himself as knowledgeable (or ignorant): his assertions should exhibit logical consistency, his beliefs ought to be rationally grounded in reasons that, upon reflection, he takes to be unquestionably or obviously true, he ought to display commitment to relations of entailment between claims, and sensitivity to conditions under which a claim may be false, including an absence of supporting reasons, and inconsistency with a well-grounded claim. ${ }^{14}$

At this point it may be useful to pause and briefly clarify what I am not claiming. I do not want to claim, as others have done, that Alcibiades learns

12 Note the emphasis on Alcibiades' answering questions about his own, somewhat settled, thoughts and convictions from $115 \mathrm{~d}-116 \mathrm{a}$ (cf. 116b-d). Socrates repeatedly asks him what he thinks (115d8, e4, e6-7), what he is prepared to say or has said (115 $\mathrm{d}_{5}$, e9-11, e15-16), based on what he would be willing to accept and what he wishes (115 $\mathrm{d}_{5}-6$, e1), and Alcibiades repeatedly answers in the first person, ascribing claims, convictions or willingness to himself $(115 \mathrm{~d} 7, \mathrm{~d} 9, \mathrm{~d} 11, \mathrm{e} 8, \mathrm{e12} ; 116 \mathrm{a} 2)$. (The current debate concerning whether or not doxa maps on to 'belief' as that term is understood (roughly) in contemporary philosophy is orthogonal to the concerns of this paper: the cognitive states I will refer to as beliefs are states of taking or endorsing such-and-such to be the case, or to be true, or states in which things appear as truly being thus-and-such endorsed by the subject, regardless of the particular Greek terms used to express this. See Moss and Schwab 2019).

13 116e-117b; cf. 118a-b.

14 Earlier in the dialogue as well, Socrates had directed him to take care that claims he endorses as belonging to himself are not inconsistent with one another (112d; cf. 111b). 
what he ought to believe consistently with his other beliefs, but which he did not previously believe..$^{15} \mathrm{He}$ learns instead what he does believe, tacitly, at the level of first-order belief, e.g. that justice is advantageous. Nor am I claiming, however, that Alcibiades all along had what is understood in the literature as the central kind of case of tacit belief, which was brought to light by Socratic questioning. For it is generally taken as a common feature of tacit beliefs, such as e.g. my belief, never previously entertained, that my sister is larger than an ant, that they are readily and immediately agreed to by the subject of belief. The actions of the agent also generally conform to the belief regarded as tacitly held in the typical sense of the term. ${ }^{16}$ Neither of these features, however, characterize the beliefs that Socrates reveals his interlocutor to possess. When asked at the outset, his interlocutors frequently avow the opposite belief and often disavow the belief in question, and they are evidently more likely to behave in accordance with that opposite belief too. Nonetheless the revealed beliefs do seem to be some kind of, i.e. some sub-set of, tacit beliefs, insofar as the subject is not previously aware of holding them, and by the interlocutor's own lights they follow immediately, or within a very small number of inferential steps, from what she is aware of believing in advance. We might say that it is a tacit belief in the sense that it is part of the way the subject antecedently took the world to be, without having previously attended to that part. A great number of beliefs belonging to this atypical (or non-paradigmatic) subset of tacit belief, moreover, will be attributable to any one of us, at any time (they include whatever immediately follows from Socrates' interlocutors' initially avowed but eventually doubtful beliefs). Socrates' interest, however, is focused on those tacit but disavowed beliefs that will upon reflection, and in light of the epistemic norms mentioned above, seem to the interlocutor to belong to him as one of his own. ${ }^{17}$ In this way he comes to know what he really thinks or believes, and so to have cognitive self-knowledge.

15 See for instance, Brickhouse and Smith 1994, 73-83.

16 Rachana Kamtekar seems to suggest that discovering one's beliefs in Plato's early dialogues via elenctic questioning amounts to discovering one's tacit beliefs in the sense described above. She writes: 'but also he doesn't know about any of the specific beliefs ... whether he believes them or not-if believing it involves accepting its entailments, acting on it, and so on' $(2017,36)$. So too Vlastos 1993, 23 with n. 63 . For an overview and critical discussion of tacit belief, see Lycan 1988. However, Kamtekar also seems to take the newly articulated beliefs, with e.g. Brickhouse and Smith, as those one ought to believe but did not previously. She writes: 'In a sense, what one does believe is determined (produced as well as discovered) by finding out what to believe through cross-examination' $(2017,36)$.

17 That is, the interlocutor himself discovers that this kind of tacit belief, though initially disavowed (or its opposite avowed), is rationally grounded and consistent with or entailed 


\subsection{The Laches and the Gorgias}

We turn now to the Laches, where, as in the Alcibiades, we again find Plato deliberately drawing attention to the distinctively subjective nature of one item of Socratic scrutiny: the cognitive states of his interlocutors in relation to the objective matter under discussion, courage. So again, Socrates' interlocutors' truth-assessable thoughts about the explicit object of investigation, courage, are themselves clearly presented by Plato as a genuine object of investigation. This must come as no surprise to Nicias: prior to the discussion of courage, he explains to Lysimachus that he knows from personal-but apparently not bitter-experience that inevitably a discussion with Socrates is ultimately an inquiry into nothing other than oneself (187e-188c). A neat example of Socrates' subjective target is given at 192by-c6 (tr. Sprague):

La.: Well then, I think [courage] is a sort of endurance of the soul, if it is necessary to say what its nature is in all these cases.

Soc.: But it is necessary, at any rate if we are to give an answer to our question. Now this is what appears (phainetai) to me: I think (egöimai) that you don't regard (phainetai) every kind of endurance as courage. The reason I think so (tekmairomai) is this: I am fairly sure (oida), Laches, that you regard (hègèi su) courage as a very fine thing.

Socrates goes on to draw out Laches further, taking care to secure the general's reflective agreement at each step that the premise under consideration is accepted as one of Laches' own claims: Socrates says that Laches values one kind of endurance, that with wisdom, as fine and noble (192c8-9); that Laches at the same time differently evaluates a different kind, that with foolishness, as harmful and injurious (192d1-2); that Laches would not call what is harmful and injurious fine, and would not allow that kind of endurance to be courage since courage is fine (192d4-9); and finally asserts that Laches' account (logos) really is what follows from these claims, that wise endurance is courage (192d10-11). Laches confirms at each point that these are his own thoughts on the matter, including the conclusion.

Now, prior to this cross-examination of his beliefs about courage, Laches had claimed to have knowledge of what courage was (190c). At its close, however,

by other well-grounded beliefs he holds, which are at the same time inconsistent with the interlocutor's initially avowed belief or claim, on the matter of significance being investigated. The extent to which the initially avowed belief conforms to these epistemic norms, or falls foul of others, e.g. in being vulnerable to an objection or having at best weak reason in support of its being the case, is left for the interlocutor to appreciate, or to investigate. 
Laches agrees that someone listening to their conversation would not be convinced that they have knowledge of courage — that they partake of it with their words (193e). Nonetheless he is not prepared to say that he lacks knowledge of courage, exclaiming instead that he seems to himself to know what it is (noein emoige dokō) but to his frustration cannot find a way to seize hold of it with words (194a-b). He is reduced by Socratic questioning to declaring honestly that he still believes himself to know, but since he cannot articulate this firstorder state, he tacitly accepts that he cannot justify the higher-order beliefclaim about that cognitive state (knowing), and so he can no longer claim to possess it with certainty.

As with the Alcibiades, Laches is repeatedly directed to think about and make claims about his own cognitive states, whether they be purported states of knowing, or states of taking something to be the case, variously described as thinking it is the case or its appearing to him to be the case. And, as with the Alcibiades, although arguably no substantive progress is made concerning the objective item of consideration, courage, the emergence of the apparent falsehood of Laches' and Nicias's first-order beliefs concerning courage constitutes negative progress. By contrast, however, considerable progress is made in the understanding the interlocutors have in relation to their own first-order cognitive states. In the case of Laches in the passage discussed above, for example, he comes to the realisation that his pre-existing beliefs (that courage is a fine thing, that foolishness is not fine), which upon reflection seem to him to be obviously true, entail the further belief that foolish endurance is not courage. So he comes to realise that in an important sense he had that belief-which was, moreover, a rationally grounded belief - all along, although he did not know it. This in turn enables him to see the implication that his previous claim, that courage is endurance, to the extent that it applies to foolish endurance, was false. And since no reasons or further considerations are in view as support for that previous claim (taken in its full generality), adherence to the epistemic norms of consistency, rational grounding, commitment to entailment relations and sensitivity to conditions of falsehood justify (and, we might think, explain) his now regarding it as false. In the process, Laches also comes to the realization that he cannot rationally defend his belief that he has knowledge of what courage is, and so that he cannot justifiably claim to know that he knows. ${ }^{18}$

18 Though there is no scope to set out and defend the claim here, the Charmides seems to provide further examples of self-conscious examination of the kind described aimed at revealing cognitive self-knowledge, most notably in the exchange with Charmides (159a162a), but arguably also with Critias (163e-164d; 165cff.). 
This process of acquiring cognitive self-knowledge is again on displayeven more pointedly —in the Gorgias, where a confident and self-assured Polus is brought by the same method of questioning to a higher-order awareness of the contents of his beliefs about justice. In a striking exchange at 474b, Socrates declares that he, Socrates, believes (oiomai) that Polus, he himself, and indeed everybody else believes (hégeisthai) that it is worse to perpetrate injustice than suffer it. Polus, in return, declares that for his part he believes that he does not (i.e. believe that it is worse to commit injustice than suffer it), and neither does anyone else, including, he implies, Socrates. ${ }^{19}$ The exchange is notable for the emphasis it places on the subjective nature of the point of contention between the two. For each declares their higher-order beliefs concerning the contents not only of his own first-order beliefs, but also those of his opponent-and indeed everyone else-concerning the relative values of committing and suffering injustice. To resolve their dispute over the content of their own and each other's first-order belief states, Socrates sets about questioning Polus. The result of the exchange, in which the epistemic norms mentioned above are again in play, is that Polus agrees that he holds a series of other beliefs that in turn commit him (or so he takes it - the merits of the finer points of the argument need not detain us) to the further belief that perpetrating injustice is worse (475b-476a). ${ }^{20}$ Socrates continues to question Polus in order to show him that he also holds additional beliefs that reveal his commitment to still further beliefs. ${ }^{21}$ As in the Alcibiades and the Laches, Socrates' questioning is designed to reveal to his interlocutor cognitive states that belong to him, the existence and contents of which he had been unaware.

Later, Callicles goes on to challenge Socrates, claiming that Polus (and before him, Gorgias) did not say what they really thought out of shame (482c-e). Here, Plato intensifies the focus of inquiry, inviting the reader not only to question the ultimate validity of Socrates' refutations of Gorgias and Polus, but also inviting her to ask: 'Did they, Gorgias and especially Polus, know their own beliefs after all and were simply ashamed to admit them, or were they ignorant

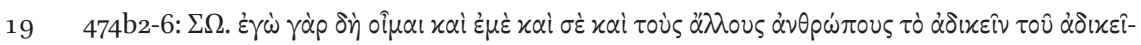

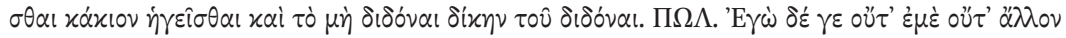

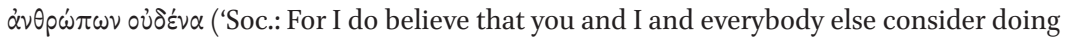
what's unjust worse than suffering it, and not paying what is due worse than paying it. Pol.: And I do believe that I don't, and that no other person does, either'; tr. D. J. Zeyl).

20 Note that Socrates emphasises that this is Polus's own opinion, pointing out that all he, Socrates, needs is a witness of one, viz. Polus, and underlining that it is 'our' (hèmin) verdict on the matter at hand (475e9-476a3).

21 For example, the belief shared with Socrates and earlier rejected by Polus as not his own, that it is not the worst thing to pay one's due in recompense for an injustice, but that getting away with it is worse (479e). 
of at least some of their beliefs, later revealed to them by Socrates?' Socrates, of course, goes on to question Callicles with the same results. ${ }^{22}$ At one point, after Callicles asserts that Socrates does not agree with him that the pleasant and the good are the same, Socrates replies at 495e1-2 that he does not, and he tellingly adds: 'and I believe that Callicles doesn't either when he comes to see himself rightly.'23 As with the other dialogues discussed, in addition to self-knowledge of their cognitive states, Polus and Callicles are introduced to epistemic norms, and are thereby given the resources to learn-even if they stoutly resist the lesson - that they are in fact ignorant about matters they declare themselves to know, and to be able to teach.

\subsection{The Elenchus and Self-Knowledge}

Before moving on to discuss Plato's own understanding of the Delphic injunction to 'know thyself' in the Alcibiades, it will be useful to underline the substantive achievement of the elenchus, correctly deployed, as regards selfknowledge. It has been hotly debated by scholars whether Plato conceived of the elenchus as enabling its practitioner to establish the truth of any claims about, or attain knowledge in relation to, the first-order objective matter of inquiry. ${ }^{24}$ In relation to self-knowledge, it has also been observed more than once in the literature that the elenchus enables the interlocutor to come to know her own ignorance. ${ }^{25}$ What has been overlooked in this debate, and what I hope to have shown here, is that one goal and achievement of the method is to bring the interlocutor to knowledge of - a correct grasp of the contents of - their pre-existing beliefs relevant to the central objective item of investigationtypically, in the early dialogues, the nature of some virtue. These beliefs need not be states which the interlocutor has previously entertained (they need not

22 Socrates gets Callicles to answer questions about his own beliefs, and secures agreement from him, at times begrudging, to claims he had earlier disavowed, notably that pleasure and goodness are not the same thing (497a; cf. 495d-e).

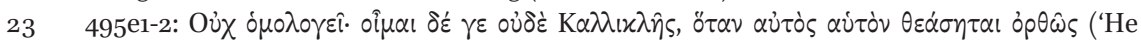
doesn't agree. And I believe that Callicles doesn't either, when he comes to see himself rightly').

24 These include Gregory Vlastos, who famously argued that Plato did so conceive of the elenchus, though he was not, strictly speaking, entitled to (1993; cf. 1983), Terence Irwin (1977, 138-41 n. 13; 315-16) and Gail Fine (1992, esp. 214), each of whom have also argued that Plato regarded the elenchus as enabling the interlocutor to arrive at truth, and Hugh Benson (1995), who has argued trenchantly that he did not.

25 For instance, Benson 2000, esp. 17-31. More recently Kamtekar has suggested that Socrates' knowledge of his own ignorance is arrived at as a result of his application of the method of cross-examination or elenchus to himself, and that the method is capable of bringing an interlocutor to grasp his own ignorance (2017, 25-38). 
have been occurrent states at some time), but are such that by the interlocutor's own lights, and in conformity with the epistemic norms employed by the method, they immediately follow from what she has previously entertained, and has reason to feel secure in. In that sense these beliefs belong in the interlocutor's belief set, and number among her commitments. And although the interlocutor was previously ignorant of that fact, the elenchus can lead her to grasp it, and so to have self-knowledge of those cognitive states. Indeed, as we have seen, it is this self-knowledge that makes possible the interlocutor's realisation of her contradictory views - and hence her own ignorance - and puts her in a position to rationally re-evaluate those views.

One core function of the elenchus, then, is positive: the work of the method is directed towards investigating the grounds or reasons the interlocutor has for beliefs hidden from her own view. By contrast, the grounds or motive for her opposing, avowed beliefs or confident claims to knowledge are not themselves the objects of scrutiny via elenchus in the dialogues. The pervasive suggestion, however, is that these opposing, avowed views are adopted on some basis other than rational reflection: Laches' knowledge-claims about courage seem to reflect culturally accepted paradigms, Nicias' proffered definition is one he asserts as based on something he once heard Socrates say, ${ }^{26}$ while Polus and Callicles consistently propound claims with which, they take it, the majority would agree. ${ }^{27}$ And, as Denyer has suggested, Alcibiades' belief that the fine and the advantageous can sometimes come apart was probably learned from the orators, ${ }^{28}$ whom he doubtless took to be authoritative. At the end of the elenctic encounter each has with Socrates, these initially avowed beliefs are seriously challenged and the interlocutor grasps (or is in a position to grasp) his own ignorance. This is not simply because the view that has emerged and opposes the initial avowed view is seen as rationally grounded, but because the interlocutor now sees that the more well-grounded view is a belief of his own (and in an important sense was his own all along). What is more,

26 Laches 19oe, 192c-e, 194c-d. For the view that Laches's definitions of courage, particularly his first definition of it as 'standing firm in battle' articulates a paradigm of courage alive in Athens at the time, see Rabbås 2004 .

27 Gorgias 471e-472c; 473e-474a; 475e-476a.

28 Denyer 2001, 145 observes that the contrast of the advantageous with the fine was, as Aristotle notes, a cliché for the orators, and was neatly illustrated by the example of Achilles neglecting his own benefit in order to courageously rescue Patroclus and so act finely (Aristotle, Rhet. 1358b38-1359a5, cf. Isocrates 4.53). Note that Olympiodorus, In Alc. 9-10 claims that Socrates instructs Alcibiades not to accept views from sources outside himself, writing 'so that his arguments would not be formed from without, like a lifeless vessel that holds water [poured] from outside' (as translated and discussed in Coope 2019). 
the self-conscious critical reflection on one's own cognitive states demanded by the elenctic method urges both the adoption of epistemic norms as one's own, and the awareness of oneself as rational, that is, as forming beliefs on the basis of one's own defensible reasons (I return to this in Section 3.3 below). Socrates' elenctic method therefore facilitates self-knowledge of cognitive states, and encourages the grasp of oneself as an inherently rational agent subject to rational norms. ${ }^{29}$

\section{$3 \quad$ Plato on Knowing Oneself in the Alcibiades}

\subsection{Interpretive Issues}

The Delphic oracle's injunction to 'know yourself' (gnōthisauton) is mentioned in a number of Plato's dialogues throughout the corpus, from the Charmidesgenerally thought to be written early in Plato's career - to the Laws - generally thought to be written late. In one so-called early dialogue, however, the Alcibiades, the oracle's exhortation is explicitly linked to an extended critical discussion of knowing oneself.30

The Delphic injunction is mentioned in association with three different passages in the dialogue. At 124b, Socrates admonishes Alcibiades to know himself as it commands. In response, Alcibiades admits that he needs to cultivate or care for himself (epimeleomai, 124b7; cf. 12oc-d ff.). Socrates next

29 Support for just this view of the elenchus is found in the description of that method in the Sophist. There, the Eleatic Stranger describes a 'noble sophist' who cleanses souls by way of ridding people of their false beliefs in their own wisdom (23ob4-231b8). He first extracts the interlocutor's beliefs and lays them side by side, exposing the oppositions or contradictions between them. This makes the interlocutor ready to expel the trouble-

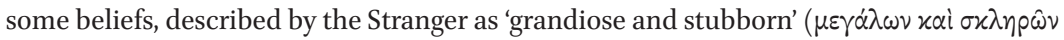
$\left.\delta \circ \xi \hat{\omega} \nu, 23 \circ c_{2}\right)$ and obstacles to knowledge. The noble sophist is described as 'expelling those beliefs that are an impediment to learning, and makes him [i.e. the interlocutor] cleansed, thinking himself to know only those things he does know, and no more' (23od2-

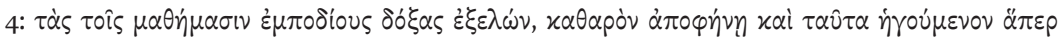

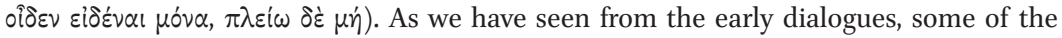
things that people rightly take themselves to know after elenctic questioning will be firstorder, such as Laches' view that only endurance that is not fool-hardy could be courageous. But others will be higher-order, such as Laches' claim, should he care to assert it, that this is indeed something that he knows.

30 There is also a link between Critias' conception of self-knowledge-a conception that is revealed to be somewhat fuzzy and difficult to understand-which he proposes as his account of what temperance consists in, and the Delphic oracle's pronouncement in the Charmides. I consider some of these difficult passages below, but for further discussion, see McCabe 2011. 
appeals to the injunction at 129a, when he suggests that in order to effect such self-care, Alcibiades ought to heed the oracle so as to know what he himself is, most of all (cf. 13oe). This turns out to be his soul. For the third and final time, the injunction is summoned to indicate that self-knowledge strictly speaking involves the apprehension of that part of the soul with which one knows and understands, and in which wisdom is located (132c, 133b-c). The somewhat cryptic passage that describes the soul's self-knowledge, containing the image of an eye seeing its image in the pupil of another's eye and presented as an analogy of the self-knowing soul (132c-133c), is difficult and ambiguous. So what Plato's interpretation of the Delphic oracle's pronouncement ultimately amounts to in the dialogue - Plato's conception of self-knowledge, or 'Platonic self-knowledge'-itself requires interpretation.

We start by noting that the inscription's introduction into the dialogue at $124 \mathrm{~b}$ marks the turning point for the vainglorious Alcibiades. By this point, as we have seen, Socrates has shown the young man that his opinions about himself were mistaken: he did not know what he really believed or what he believed himself to know concerning justice and injustice, and the good of the polis. As well as lacking a proper grasp of his cognitive states, he is also shown to fail to appreciate his general state of being unknowing, uneducated and only moderately wealthy - that is, as unaware of his abilities and material resources in comparison with other prospective national leaders. After the first appearance of the Delphic inscription, then, self-knowledge in Plato's hands appears to incorporate knowing one's own cognitive states as just one part of what it is to know oneself. On this reading, the object of Platonic self-knowledge would be broader than cognitive self-knowledge, also incorporating knowledge of relational and political facts about oneself, such as one's social standing and material resources (as some scholars have contended). ${ }^{31}$ In line with this complex and outward-looking view of the self and self-knowledge, the majority of scholars take the second and third invocation of the inscription together as suggesting that we see a reflection of ourselves in our relations or interactions with others, and thereby gain self-knowledge. This thought can be fleshed out in a number of ways. The soul's self-knowledge could be regarded as necessarily facilitated by the subject's cognitive grasp, via dialogue with another, of the content of that other person's thought or knowledge about the subject herself-about her soul, its contents, its ability to reason, or its activity of knowing. On this reading, the content of the other person's thought is taken as an image or representation of the self-knower's soul, or its contents, abilities or activities: the soul sees itself or its contents in the mind of another, as if it 
were a reflection. Alternatively, the soul's ability to know itself could be taken to depend upon the subject's apprehension of the soul of another person, or its contents, abilities or activities, together with the realization that the two souls are alike in this respect. On this view the soul sees itself or its contents as being just like that of another, which thus acts as a kind of reflection.

Against these readings, however, I will argue for an alternative interpretation. I begin by suggesting that a close reading of the text reveals successive refinements and so a narrowing of the proper or fundamental object of Platonic self-knowledge that excludes the social and the corporeal, yet retains the mark of individuality. ${ }^{32}$ Secondly, I will argue that the point of the analogy with the self-seeing eye in the final passage is to establish that, analogously with an eye, the soul's activity is only directed at itself if some mechanism is employed to alter its typically non-reflexive relation to its object, so that it becomes reflexive. In the case of the eye, the mechanism must be external, and requires an external reflective surface, while in the case of the soul, its view of itself is delivered by standing in a higher-order relation to lower-order activity. Since the mechanism for the soul's grasp of its best and proper activity is reflective, higher-order thought, it is able to accomplish this either directly (i.e. on its own and without recourse to anything external to itself), or indirectly, in conversation with another.

In relation to the object of self-knowledge, notice first that Socrates shifts the focus from the normative claim that one ought to know oneself to the question of what the proper object of self-knowledge is. At 129b1 he asks how they might find out what the 'itself' alluded to in the Delphic inscription is, in itself, and proceeds to argue that this is what oneself is, rather than what belongs to oneself. ${ }^{33}$ This is then said to be the soul as opposed to the body or material possessions, which are used as belongings. He infers that the injunction to know oneself just is the command to know one's soul (13oe8-9; cf. 131b-c), an explicit modification of the earlier, much broader characterization of self-knowledge as incorporating a correct grasp of social and material facts about oneself. The second and final corrective refinement of the object of self-knowledge is signalled by the suggestion that they had previously misunderstood the

$3^{2}$ Hence the proposed reading is to be distinguished from that which takes the Alcibiades to suggest that self-knowledge consists in apprehending oneself as a rational being in contrast to knowing features of oneself qua individual, such as one's social position, character, values, beliefs or desires. See e.g. Johnson 1999.

33 For detailed discussion of the view that the subject here is the 'itself', rather than some notion of the 'self' more familiar to modern or contemporary readers, see Gill 2007. 
inscription (132c9-10). ${ }^{34}$ Socrates then indicates by way of the eye-soul analogy that self-knowledge requires the soul to see (blepein) and properly grasp (gignōskein) that region (topos) of itself in which its good activity or virtue (aretē) occurs (identified as knowing, understanding, and wisdom), as well as to apprehend understanding (phronēsis). Socrates says that a person who grasps this also grasps himself most of all (malista, 133c6), and evidently identifies this with knowing oneself (132c7-10). The final, fully refined conception of the object of self-knowledge is, therefore, confined to the finest activity of soul, virtue, in contrast to properties or features of the subject constituted by her relations to others or her corporeality. The purpose of these refinements becomes clear in the context of Alcibiades' goal of self-cultivation (123d-e, 124b, d): if Alcibiades is most of all the part of his soul capable of knowledge and wisdom, then its excellence will be his excellence, the goal of self-improvement. Platonic self-knowledge thus brings the goal of self-cultivation into focus. As I will argue below (Section 3.3), cognitive self-knowledge is a necessary component of Platonic self-knowledge, as is the adoption of the epistemic norms at play in the elenctic method.

\subsection{The 'Reflective Soul' Reading of the Analogy}

I turn now to the interpretation of the eye-soul analogy as pointing to the need for a mechanism to transform the normally non-reflexive relation between the soul and its object into a reflexive relation. But since this is at odds with the interpretation of the analogy given by most commentators-including a very recent contributor to this journal, Daniel Ferguson (2019) - according to which the analogy suggests that self-knowledge requires something external to the soul to reflect or mirror it (or its contents or characteristics) back to itself, I shall first provide an argument against that reading.

The directedness of intentional thought invites an analogy with vision. Sight is always directed at something, and seeing is always a seeing of something, no matter how indeterminate or vague. So too the cognitive activity of the soul exhibits directedness in being intentional, in being about something. In vision, the directed relation between the seeing eye and its object is strictly nonreflexive, so that the eye requires a mirroring surface in order to see an image of itself reflected back to itself. But the text ought not be taken to suggest that the self-knowing relation, like the self-seeing relation, is necessarily mediated by something external to the soul which affords a reflected image of the soul

34 Socrates says: 'But by the Gods, didn't we understand that admirable inscription from

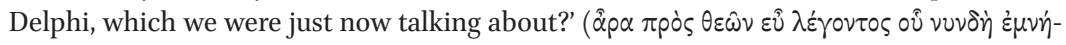

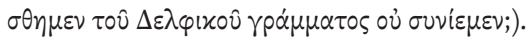


or its activity, for two reasons. First, there is no textual evidence of reflection or mirroring in the case of the soul. Secondly, a passage in the Charmides constitutes strong evidence against attributing such a view (arguably, a questionable view) to Plato. I begin by quoting the relevant section from the Alcibiades in full (132d1-133c7, tr. Hutchinson, modified):

Soc.: I'll tell you what I suspect that inscription means, and what advice it's giving us. There may not be many examples of it, except the case of sight.

Alc.: What do you mean by that?

Soc.: You think about it, too. If the inscription took our eyes to be men and advised them, 'See yourself', how would we understand such advice? Shouldn't the eye be looking at something in which it could see itself?

Alc.: Obviously.

Soc.: Then let's think of something that allows us to see both it and ourselves when we look at it.

Alc.: Obviously, Socrates, you mean mirrors and that sort of thing.

Soc.: Quite right. And isn't there something like that in the eye, with which we see?

Alc.: Certainly.

Soc.: I'm sure you've noticed that when a man looks into an eye his face appears in the pupil (opsis) of the one opposite, like in a mirror. We call this the 'pupil' (korē), for it's a kind of image of the man who's looking.

Alc.: You're right.

Soc.: Then an eye will see itself if it observes an eye and looks at the best part of it, the part with which it can see.

Alc.: So it seems.

Soc.: But it won't see itself if it looks at anything else in a man, or anything else at all, unless it's similar to the eye.

Alc.: You're right.

Soc.: So if an eye is to see itself, it must look at an eye, and at that region of it in which the good activity (aretē) of an eye actually occurs, and this, I presume, is a pupil (opsis).

Alc.: That's right.

Soc.: Then if the soul, Alcibiades, is to know itself, it must look at a soul, and especially at that region in which the good activity (aretē) of the soul, wisdom, comes about, and at anything else which is similar to it.

Alc.: I agree with you, Socrates.

Soc.: Can we say that there is anything about the soul which is more divine that that where knowing and understanding take place? 
Alc.: No, we can't.

Soc.: So this part of it is like god, and one who looks to this and knows everything divine, both god and wisdom, would know himself most of all. Alc.: It seems so. ${ }^{35}$

If Plato had wanted Socrates to say that the soul, or its characteristics or activities were reflected back to it, he could have very easily done so. Similarly, he could have written that in order for the soul to know itself it must look to another soul if he had wanted to. But in both cases, he did not.

In response to this obstacle to the 'reflective soul' reading, Ferguson first concedes that it 'must be admitted that nothing in the analogy itself explicitly characterises the soul as reflective', before arguing that weaker textual evidence can be found a little later in the dialogue. ${ }^{36}$ At $134 \mathrm{~d}_{5}$, there is a description of what is almost certainly the soul as 'bright' (lampron), and which very likely refers back to the eye-soul analogy. Since Plato uses this term elsewhere to describe a reflective surface (Tim. $7 \mathrm{lb} 2$ and $72 \mathrm{c} 3$ are cited), Ferguson concludes that it can be read as making explicit what (in his view) was implicit in the analogy, viz. the reflective nature of the soul. The suggestion, however, is dubious. Although Plato does use lampron to describe reflective surfaces, he much more often uses it to describe something as having the property of being brilliant, luminous or exceptional in some respect, and not as being reflective. So

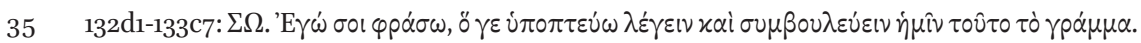

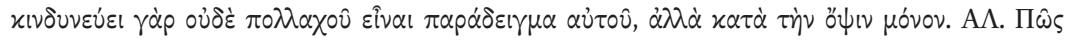

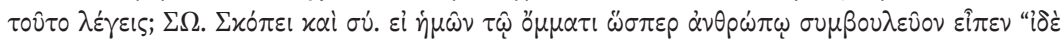

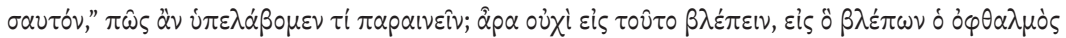

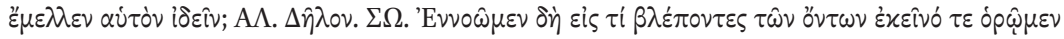

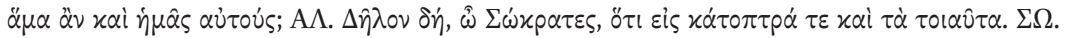

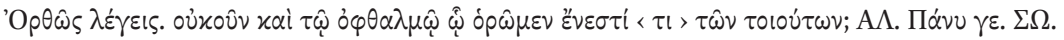

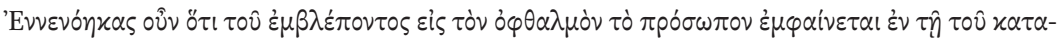

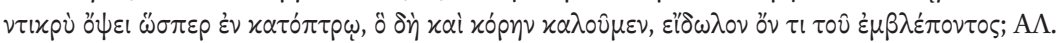

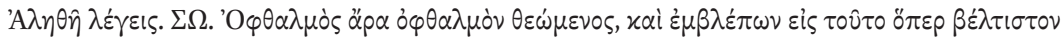

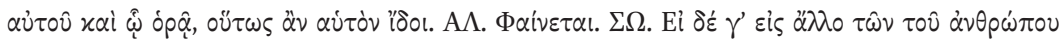

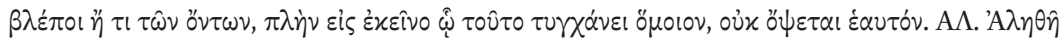

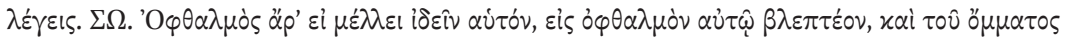

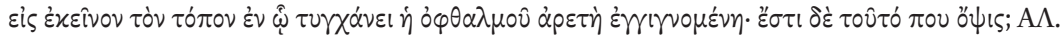

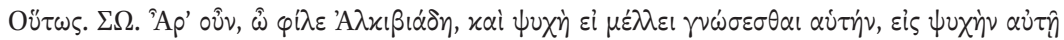

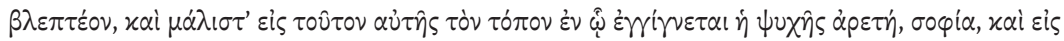

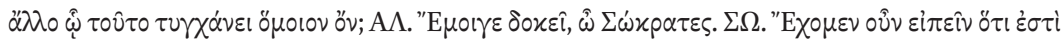

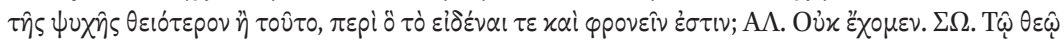

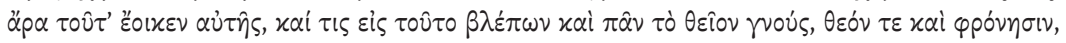

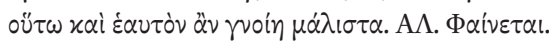

36 Ferguson 2019, 380. For further discussion, see Tarrant 2015. 
Plato's occasional use of the term to indicate reflectiveness in other dialogues on its own tells us nothing about his use of it at Alc. $134 \mathrm{~d} 5$.

Indeed, closer examination of his use of the term elsewhere reveals compelling evidence for reading it at $134 \mathrm{~d} 5$ as indicating the non-reflective sense of being brilliant as opposed to the reflective sense. Of the twenty-two other uses by Plato, eighteen clearly carry the 'brilliance' sense of lampron, whether applied to physical or non-physical objects. ${ }^{37}$ This sense of lampron is also used of objects that are divine. In the Sophist, the philosopher is said to be hard to discern because of his proximity to the form of Being and the resulting brightness of the general area (254a9). The Stranger then remarks on the difficulty of keeping the soul's eyes on the divine. In the Timaeus, Timaeus says the demiurge made the divine class (the stars) out of fire in order that they be as bright as possible (lamprotaton, 40a3) and most beautiful - the order of explanation suggesting that superlative brilliance is most fitting for the divine. By contrast, the four uses of lampron that describe a reflective surface all refer to physical entities, and couple the term with 'smooth' (leion): in the Timaeus, reflection is explained as fire from the reflected object meeting the fire of vision on a 'smooth and bright' surface (leion kai lampron, 46b3); in a later passage, which Ferguson cites, the liver is described at $71 \mathrm{~b} 2$ as fashioned as 'bright and smooth' (leion kai lampron) so that thoughts move in it 'as in a mirror', and at $72 \mathrm{c} 3$ it is again said to be bright and likened to a mirror; in the Sophist, reflections are described as resulting from light hitting surfaces that are 'bright and smooth' (lampra kai leia) at 266c2.

Now, at Alc. 134d1-8, Socrates says that, as they have previously discussed $\left(\mathrm{d}_{4}\right)$, Alcibiades and the city will look towards what is 'bright and divine' in becoming temperate and just, and in doing so will see and know themselves. The backwards reference strongly suggests the part of the soul discussed earlier in the analogy, which was described as being divine (133c1; cf. c4, c5). There is no talk here at $134 \mathrm{~d} 4-5$ (or elsewhere) of reflections or of functioning 'as a mirror', and the term 'smooth' (leion) is also absent. So, contra Ferguson, there is no evidence of the 'reflective' sense of lampron. Moreover, the object described, the soul, is presumably one that Plato takes to be a non-physical object. ${ }^{38}$ These factors, together with the coupling of lampron with the divine at $134 \mathrm{~d} 5$ (echoing the association of the best part of the soul as divine at 133c), makes

In these eighteen occurrences, lampron describes something not as a reflective surface but as bright (e.g. sounds, $P h l b .5_{11 d}$ ), brilliant (e.g. the sun, Tht. $208 \mathrm{~d} 2$ ), luminous (e.g. light, Rep. 616b6, e9; copper, Ti. 59c2) or exceptional (e.g. a person, Grg. 484e4; Agathon's wisdom, Symp. 175e4). See also Phd. 110c2, Sph. 254a9, Phdr. 25ob6, Hipp. Mi. 368d7, Ti. 40a3, 6oa6, 68a7, 68b5, 68c5, Rep. 518a8, 56oe3. 
it certain, in my view, that the 'brilliance' sense of lampron is being employed. We must conclude, then, that reading our text as suggesting that the soul, like the eye's pupil, is reflective, is specious. ${ }^{39}$

The second problem for the 'reflective soul' reading is that it requires attributing a view to Plato that the Charmides shows him unlikely to have accepted. On the reflective soul reading, just as an eye cannot on its own directly see that part of itself with which it sees, so too a soul cannot on its own directly apprehend that region of itself with which it knows and is wise: in both cases another just like it is required to reflect it, or its best activity, back to itself. On this reading, Plato regards the soul's directly knowing itself knowing as an impossibility. The Charmides, however, tells against this.

At 167 c-169c Socrates asks whether any faculties or powers can be applied to themselves. Each faculty has a proprietary kind of object: colour is the proper object of sight, pleasure of desire, opinions of the opinable, so that e.g. there is no seeing that does not see some colour $(167 \mathrm{c}-\mathrm{d}, 168 \mathrm{~d}-\mathrm{e})$. If we understand the idea of a power applying to itself as the exercise of that power at a higherorder level directed to its exercise at the first-order level, then the higher-order exercise of a power would only be possible if the first-order activity possessed the relevant features of the object proprietary to that power. So if seeing of seeing is possible, first-order seeing will have to be coloured, and so visible to higher-order seeing, and if opining of opining is possible, first-order believing will itself have to be opinable, and so available to the higher-order activity. ${ }^{40}$ Next, and importantly for my purposes in this paper, Socrates argues against the application of the faculties of perception to themselves, in contrast to the application of the faculty of knowing to itself. For, he reasons, it is doubtful that seeing is itself coloured, or that hearing itself possesses sound (168c-d) ${ }^{41}$ The perceptual case is sharply contrasted with the epistemic case: Socrates gives a careful and credible analysis of the higher-order state of knowing one's own knowing, in which the content of first-order knowing is embedded in the

39 Another, speculative, alternative is to amend the text in such a way that it does suggest the soul's reflectiveness, an alternative argued for by Tarrant 2105. However, since Tarrant's reasoning proceeds from the assumption that the 'reflective soul' reading must be correct, the speculative emendation cannot count as a consideration in favour of that reading.

40 Socrates does not say what the defining characteristic of the opinable is - perhaps, we might think, it is what is truth-apt.

41 He also points to the material causal relations involved in sensation, and treats them, it seems, either as cases of motion and heat, or as like those cases: it would produce disbelief, he says, to suggest that any sort of motion could move itself, or heat burn itself (168e169a). Although his precise meaning here is not clear, his point seems to be the plausible thought that a material activity, constituted by causal relations and itself an actualisation of a power, cannot act upon itself. 
content of the higher-order state. His example is the doctor who knows, of his own words and deeds (and those of others), that they accord with knowledge of health. He thus knows himself to be a knower of medicine in knowing what he knows (as opposed to knowing merely that he knows) (17ob-d). This conception of the higher-order state of knowing one's own knowing makes trouble for Critias' (most recent) account of self-knowledge in that dialogue as knowing (merely) that one knows. But the nature and possibility of the higher-order state, and so this case of a power that applies to itself, is never doubted.

Only the direct application of a power to itself is considered in the passages from the Charmides - seeing indirectly, by way of mirrors, is not discussed. This is because Socrates' concern is with whether and in what way powers by their nature apply to themselves (169a3-4). To this inquiry, seeing via reflection is irrelevant. For the object of seeing in this case is not-and by definition cannot be-the subject of seeing, since a reflection is an image of that subject. To be sure, it is visible (it is coloured), and it constitutes strong visual evidence concerning that subject (under normal circumstances). But it ought not be confused with that subject: seeing (an image of) oneself seeing in a mirror is not higher-order seeing. ${ }^{42}$ By contrast, Socrates suggests, higher-order cognition can be directed at lower-order cognition. By way of embedded content, the lower-order state (of believing, or knowing) is made available (believable, knowable) to the higher-order state. What Plato argues in the Charmides, then, is that direct, reflexive relations between higher- and lower-order states of knowing are possible (and in some cases, actual), while they are not possible in the case of perception. This in turn casts doubt on the presumption, crucial to the 'reflective soul' reading of the Alcibiades, that in Plato's view, the soul, like the eye, stands in need of an external mechanism to make itself available, or its own knowing and understanding available, to itself, as something it can grasp by way of an indirect relation.

\subsection{The Proposed Reading of the Eye-Soul Analogy}

A more attractive and plausible reading of the analogy, I suggest, is that it is designed to make two, related points. One is that in order for the soul's apprehension to be of itself, its cognitive gaze - which, just like that of the eye, is usually directed towards something other than itself-must become reflexive. In the case of an eye, a mirror is needed to mediate its seeing an image of itself. In the case of the soul, however, as we have been shown in the earlier, elenctic passages in the dialogue, a higher-order (and so directly reflexive) form of

42 Contra Zina Giannopoulou, who writes that the eye-soul analogy in the Alcibiades describes a case of second-order seeing $(2015,77-9)$. 
thought, directed at lower-order thought in the soul, is possible (and which I discuss further below). So no such mediation or external mirroring is needed for the soul, for which reason none is specified.

The second point addresses the overarching question that frames the analogy at the start of our passage: how to get the clearest knowledge of ourselves (132c7). In the context of this question, Socrates points out that for an eye to be self-seeing, it is not enough that it looks at an eye, but rather must look at that part of it, the pupil (opsis), with which it engages in its central activity, seeing (this is tracked by the string of datives from 133 a 6 to bio). In so doing it gets the clearest view of what the eye really is, since it views that region of it with which its defining activity occurs. Moreover, as Jacques Brunschwig has pointed out, there is evidence that the Greeks thought that the small images that appear on the surface of the eye in the pupil, visible when looking at one's own reflected pupil or directly at another's pupil, were themselves causally implicated in, and so part of, the activity of seeing (1973, 24-5). If so, seeing an image in another person's pupil would have been regarded as seeing seeing-seeing the other's pupil engaged in seeing. Similarly, viewing one's own image reflected in one's own pupil by way of a mirror or reflective surface, that is, viewing an image of one's own pupil, in which an image (of oneself) is reflected, would be a case of seeing an image, in the mirror, of oneself seeing.

Analogously, then, the soul will know itself properly when it cognizes that region of itself with which it engages in its central or defining activity, and grasps itself engaged in this activity. Neither this activity nor the region or element in the soul responsible for it is named in our passage, but the excellence of the soul is identified as wisdom (sophia), and the region or element in question is described as that in which (or with which) knowing (to eidenai) and understanding (phronein) arise (133b7-c2). Moreover, the soul that knows itself most of all is said to be that which apprehends this region, and its own understanding (phronessis). Since it is unmediated, this grasp is presented as direct, and is, I submit, the higher-order state of correctly apprehending one's own cognitive activity directed at knowing and understanding, and the part of one's soul that engages in this activity when it is done well.

Now, as we saw earlier, as a result of Socratic questioning in the elenchus, Alcibiades came to reflect on his own activity of believing and states that he took to be those of understanding or knowing. He also became cognisant of a number of his own beliefs that were previously hidden from his awareness, and in addition, finding himself avowing inconsistent beliefs, grasped his own state of ignorance on questions of justice and the well-being of the polis. Through the elenchus he gained cognitive self-knowledge, a higher-order and reflective grasp of the content of lower-order states of which he was 
previously unaware, and of himself as ignorant about matters he previously took himself to know. However, Socrates' twice-refined conception of selfknowledge, described with the aid of the analogy_Platonic self-knowledge in the Alcibiades - should not be identified with this higher-order grasp. That is, although cognitive self-knowledge is a necessary condition for, and a crucial element of, Platonic self-knowledge, it is not sufficient for it. What is needed in addition, as we are told in the eye-soul analogy, is apprehension of the part of the soul capable of knowing, and in which its best activity and excellence, wisdom, occurs.

Although it is distinct from it, this further grasp is nonetheless facilitatedthough not guaranteed-by cognitive self-knowledge, and the method at its core, the elenctic method. For, as we have seen above, that method invites and encourages its practitioner to self-consciously observe the epistemic norms that inform its use. We have also seen that the agent who uses the method comes to see for herself that, by her own lights, i.e. in accordance with beliefs she was antecedently committed to and by her own reasoning, she in fact holds beliefs the opposite of which she had previously avowed. The epistemic norms thus yield substantial results for the agent, and thereby provide her with a strong reason to adopt them as her own. If she does so, and if she deploys the method habitually — as Alcibiades famously did not—she will, moreover, develop a pattern of critical and reflective higher-order scrutiny of her firstorder thinking directed towards the truth. Her truth-apt thinking will become self-conscious, and self-consciously mediated by norms that reason tells her will result in views that conform, as far as the evidence available to her allows it, to the way the world in fact is. The agent will then be in a position to grasp her own power to rationally scrutinise the grounds for her views, and to continue to hold only those that are rationally grounded (on some given subject). She thereby apprehends the distinctive part of herself with which she engages in truth-directed cognition and with which she is able, at times, to do it well or excellently. That is, she apprehends that part or aspect of herself in virtue of which she is a rational agent, capable of knowledge and wisdom. The agent who does this, as well as correctly ascertaining the contents of her own beliefs on matters she takes to be significant, eschews those that upon reflection do not seem to her to be rationally grounded, and has a correct estimation of her own states of knowing (or of ignorance), is the agent who possesses Platonic self-knowledge.

The account thus far might be taken to suggest that self-knowledge in Plato's early dialogues — both cognitive and Platonic — is the result of a strictly solo pursuit. However, the focus on the role of language in the presentation of thought in the Alcibiades strongly suggests otherwise. At 13od-e Socrates 
claims that the mechanism by which one soul is in contact with another soul is linguistic, by way of words in conversation (cf. $129 \mathrm{~b}-\mathrm{c}) \cdot{ }^{43}$ And indeed the medium in which elenchus takes place, by which Alcibiades was able properly to grasp his cognitive states and condition of ignorance, was linguistic: by articulating his views in words, he was able to regard these first-order thoughts at a higher-order level. And, although Alcibiades accomplishes his higher-order grasp of lower-order cognitions in conversation with another, it would seem rash to attribute to Plato the highly questionable claim that one can only apprehend one's own thought by reflecting on its articulation in conversation with another person. We can instead read him as depicting Socrates as guiding Alcibiades in a practice of critical reflection that, once mastered, can be enacted on one's own, as well as with others. ${ }^{44}$ It is worth noting that Plato would go on later in his career to characterise thought as the soul's silent conversation with itself (Tht. 189e-19oa, Sph. 263e-264a, Phlb. 38d-39b), and in one dialogue explicitly to regard this inner conversation as the exchange of statements (logoi, Sph. 262b-e) ${ }^{45}$ Elenctic questioning and cognitive selfknowledge — and so also Platonic self-knowledge—can be pursued on one's own, or together with another.

Epistemic Authority and Dialogue

I turn now to the question of epistemic authority. Thus far, I have argued that at the core of Plato's own conception of self-knowledge in the AlcibiadesPlatonic self-knowledge - lies cognitive self-knowledge, a state which is shown in a number of early dialogues to consist in a reflected-upon, higher-order

43 The context of the suggestion at 13od-e (and earlier at 129b-c) is Socrates' claim that what a person really is, and what is therefore identified as the proper object of self-knowledge, is the soul as opposed to the body: a conversation is not, strictly speaking, two people saying things to one another face to face, but two souls addressing one another with words.

44 Note, too, that if self-knowledge is achieved via conversation with another, and so involves something external to the subject, it is not the case that one's thoughts are 'mirrored' back to oneself in the conversation: words are audible manifestations or expressions of thought for Plato (Sph. 263e), not images of them. If they are images (sometimes, or always), they are for Plato images of the intentional objects of the thoughts so expressed (Sph. 234c).

45 In the Philebus, the account is supplemented by the addition of illustrative images in the soul, said to occur alongside statements or judgements (39b-c). To be sure, these dialogues are all thought to have been written much later in Plato's career. However, there is no reason that I am aware of to think that this conception of thought represents a change of mind on Plato's part. 
reflexive grasp of the contents of one's cognitive states. This grasp is, moreover, a direct grasp, though it can be made possible by conversation with another. And we might think that a particular kind of epistemic authority comes with directly reflexive, first-personal self-knowledge, namely first-personal epistemic authority. As Myles Burnyeat observed some years ago, however, it would be a mistake to attribute to Plato, or Greek thinkers generally, a commitment to the kind of first-personal epistemic authority thought to follow from the distinctly Cartesian conception of subjective truth immune to hyperbolic doubt. ${ }^{46}$ On the account of self-knowledge proposed here, too, there is no room for this kind of first-personal authority: we have seen that in Plato's view we can be mistaken, as Socrates' interlocutors frequently are mistaken, about the contents of our own beliefs. The absence of epistemic authority invested in the first-personal perspective is strikingly evident, as Raphael Woolf has pointed out $(2008,26-8)$, in the exchange between Polus and Socrates at Gorgias 474b, discussed above. Polus' response to Socrates' assertion that he, Polus, believes that it is better to suffer injustice than perpetrate it is one of indignant denial, but not because he thinks he has special first-personal access to the content of his own beliefs. Rather, Polus denies believing it because he thinks nobody believes it. Occupying the first-personal position does not on its own confer epistemic privilege or secure special access to the content of belief.

Now, Woolf went on to suggest that Plato in fact depicted third-personal epistemic authority in the early dialogues generally, whereby interlocutors, particularly Socrates, claim to know, and indeed do know, their opponent's or interlocutor's beliefs better than they do themselves. Woolf also points out that in the Apology others besides Socrates are also said to practice the method (23c5-d9), and so, presumably, are similarly able to discern their interlocutors' beliefs better than they are themselves. Woolf went on to challenge those readers of the dialogues who, as I do here, take Plato to show his characters coming to know their own ignorance via the elenchus, and so to enjoy first-personal knowledge of the contents of their own minds (to that extent, at least). He argued that the case of Socrates, who is presented as having self-knowledge of his ignorance, is rare by design in the dialogues: Plato thought — rightlythat one cannot simultaneously assert and doubt a proposition, since doubt requires disavowal of the claim to be doubted as one's own. So, a person cannot doubt her own beliefs, and by a method of critical questioning, come to

46 Burnyeat 1982. For further discussion in connection with the topic of self-knowledge, see Leigh 2020, 3-9. 
see the falsity of her own beliefs, and her own ignorance, but only the falsity of propositions. ${ }^{47}$

Against Woolf's reading, I hope to have provided a number of textual reasons to doubt the contention that cognitive self-knowledge was considered rare or impossible by Plato. Not only does Socrates' repeated insistence on his awareness of his own ignorance suggest, pace Woolf, that Plato thought this first-personal state possible, we have seen that Alcibiades becomes aware of his own ignorance via elenctic questioning (117a-b; 118a-b). So too in the Laches, Nicias acknowledges his own ignorance (199e; 200a-c) and, as we have seen, although Laches continues to think he really has knowledge of what courage is, he becomes aware that he is not entitled to claim knowledge, since he cannot say what it is. More importantly, I hope to have shown that cognitive self-knowledge in Plato is not predicated on simultaneously doubting and affirming a single proposition. Rather, the elenctic method leads the interlocutor to grasp - and in that sense come to know-beliefs she possessed all along, some of which contradict a belief she espoused at the outset, which contradiction reveals her ignorance to herself. It is the set of rationally grounded positive beliefs that are the direct target of elenctic questioning, the apprehension of which is its aim, not the entertaining of doubt concerning the initially avowed belief. To be sure, doubt seems certain to follow for the interlocutor who finds herself holding contradictory beliefs, but as I understand it, it is no part of the method's procedure. There is no reason, then, to take Plato to think that someone armed with the elenchus and occupying the third-personal viewpoint is in a special logical or epistemic position vis-à-vis the content of their interlocutor's thought, and so no reason to read Plato as endorsing third-personal epistemic authority. And finally, we can be certain that for Plato no special authority is bestowed simply by occupying the third-personal perspectivePolus thought he knew better than Socrates what he, Socrates, thought, but turned out to be mistaken.

If the foregoing is right, the warrant for claiming to know what one believes, or knows, does not flow from inhabiting a particular viewpoint, according to Plato. All the same, I have argued that Plato did endorse first-personal, higherorder knowledge of lower-order cognitive states, i.e. cognitive self-knowledge. On this interpretation, epistemic warrant and authority flows not from viewpoint, but from the normative nature of rational reflection and enquiry, i.e. from the subject's adherence to the epistemic norms we have seen in operation in the early dialogues discussed. The method of cross-examination is

47 So, Woolf argues, Plato could not account philosophically for the self-knowledge he depicts Socrates as possessing: $2008,34-7$. 
performed well when the epistemic norms articulated above are adhered to, by engaging in critical reflection on the evidence or grounds for or against the truth of the individual claims or premises used in the inquiry, and grasping the inferential or explanatory connections between them. Adherence to epistemic norms is, therefore, a necessary condition for entitlement to make a judgment about the content of cognitive states.

A further condition can be read into Socrates' emphasising to Alcibiades the importance of only agreeing with a claim when he hears himself say it (Alc. 114e), that is, of undergoing critical reflection (according to the epistemic norms) himself: for self-knowledge of cognitive states, the agent must herself carefully reflect upon, and come to grasp for herself, beliefs she holds for good reason, by grasping the warrant for, and connections between, premises herself. The context of her doing so may well be conversation with another but, on the normative standards presented in the early dialogues, the agent does not properly grasp that she believes thus-and-such unless she grasps in what way, given her set of relevant commitments, she believes it and has, moreover, reflected critically on the rational grounds, evidential or conceptual, for those commitments. What is ruled out, then, is her gaining self-knowledge by accepting the authority of another, even if the other's reasoning about the agent's cognitive states adheres perfectly to the epistemic norms. To the extent that self-knowledge of cognitive states requires the agent herself to grasp the reasons she has for her lower-order beliefs in order to self-consciously endorse them, then, Plato is an internalist about cognitive self-knowledge. On the interpretation argued for here, then, a limited kind of first-personal epistemic authority - and with it, responsibility—accrues to the agent. It is limited in the sense that the agent's viewpoint is not in itself epistemically privileged, which is why she may be mistaken about the contents of her beliefs where others are not. But since self-knowledge for Plato requires one's own grasp of one's own reasons, self-knowledge demands that she not abdicate epistemic authority to another.

At the same time, a role for the other remains, and along with it a certain kind of (similarly limited) epistemic authority. I have argued that the selfknowing agent comes to enjoy a critically reflective and self-conscious awareness of the content of her set of first-order beliefs concerning some objective matter and the interconnected reasons she has for them, evaluated in accordance with epistemic norms. But even though she may have spent considerable effort reflecting, and have reflected well, the agent may doubt that she has attained cognitive self-knowledge. Perhaps, although her first-order beliefs about the objective matter in question are plausible given her experience and the information available to her, she made a subtle inferential error without 
noticing, or failed to identify all her beliefs relevant to the matter at hand because an objective causal or explanatory connection is as yet obscure to her. To be sure, in cases where there is an established body of expert knowledge concerning the object of inquiry, it will be open to the agent to determine the truth or falsehood of her views by comparing them against the authoritative views of the experts, who will in turn be able to offer explanations and make inferential connections that on her own she cannot, but which she can understand. She will then be in a position to reflect on the information she has gathered and her set of beliefs at the first-order level in order to reappraise them. In contrast to such cases, however, in respect of the objective areas of investigation Socrates deemed most important- those central to moral and aesthetic inquiry - there are no experts or established bodies of knowledge. So, as regards these issues, the agent can never be sure that she has adequately critically reflected on her first-order commitments, and so that she has achieved cognitive self-knowledge. Moreover, the self-conscious nature of the elenctic method and of Platonic self-knowledge, as I have understood these here, ensures that the agent would be aware of this lack of certainty. ${ }^{48}$

In the face of these difficulties within the moral and aesthetic domain, the best option available to the agent is to engage in dialogue with others on the question at hand, and thereby examine her beliefs on the issue alongside the beliefs of others. Since both parties are equally able to evaluate their claims, beliefs, inferences and explanations in terms of the epistemic norms, they are able together to arrive at agreement about what they think, upon critical reflection. Where the deliverances of this dialectical or joint self-examination are at odds with the results of previous solo self-examination, and provided the norms are adhered to, the former ought to be regarded as authoritative with respect to the latter. This is because if I now, in talking with you, come to take myself to have had reason all along to regard some view as my own, this suggests there is something that I had overlooked before, or not considered

48 See Apol. 22d, where Socrates says he was able to determine by way of elenctic questioning that craftsmen were knowledgeable in respect of their crafts, and wiser than he (being unknowledgeable) in these respects: the passage can be taken to imply Plato's endorsement of a conditional kind of epistemic authority in the case of testimony from experts in the crafts (plausibly extended to sciences, e.g. medical and mathematical sciences). The authority is conditional, even in the case of experts, on the agent being able to establish their being knowlegeable for herself, although precisely how she is to determine this is not specified. (For a discussion of epistemic authority more broadly, and the suggestion that Cicero and Olympiodorus, inspired by Socrates in the Alcibiades and elsewhere, cautioned against adopting beliefs as such simply on the authority of others even in the case of acknowledged experts in the relevant domain, though for very different reasons, see Coope 2019.) 
carefully enough when reflecting by myself. To be sure, I may later change my mind. But if I do so, I had better be able to go back to you and convince you of the reasons for my change of heart, in accordance with the relevant norms. For Plato, on this reading, critical reflection on our own opinions and convictions is most profitably undertaken together with others, and the conclusions we come to as a result of solo self-examination ought to be tested in dialectical engagement with others.

This reading also suggests that, when restricted to examining ourselves by ourselves, one epistemically beneficial way of proceeding would be to imagine ourselves in conversation with another, in order to imaginatively adopt a perspective other than our own from which to critically appraise those claims we are inclined to endorse, as far as that is possible. Such imaginative efforts could not be as authoritative as critical conversation with another, but would most closely approximate this ideal epistemic situation. In turn this (admittedly speculative) suggestion is able to make sense of an otherwise puzzling feature of the dialogues in connection with self-knowledge. First, as Woolf has pointed out, Plato nowhere depicts Socrates or any other character in his dialogues gaining self-knowledge by undergoing solo self-examination in any straightforward way. ${ }^{49}$ We can now see that this is not because Plato harboured doubts about the possibility of self-knowledge (cognitive or Platonic): Plato did not present his readers with a model of solo first-personal examination because his preferred method of inquiry into one's own states, as well as into objective matters, was that of joint inquiry, and this is what he models, over and over, to his reader. An illustration of solo self-examination as approximation of examination together with another is found in the Hippias Major. That dialogue ends with Socrates reporting at length a critical conversation he had with an unnamed person who turns out to be none other than Socrates himself $(298 \mathrm{~b}-304 \mathrm{e})$. The scene is certainly strange: Socrates seems first to pretend (to himself) that he is conversing with someone else, and then to pretend (to himself) to be that other person in criticizing what he, Socrates, has just said. For all its peculiarity, however, the pretence is self-conscious-as Socrates' report to Hippias makes plain, there can be no doubt that Socrates was aware of conversing with himself. So, in contrast to Woolf, who reads the strangeness of the scene as indicating a resistance on Plato's part to depict first-personal conversation, I suggest we read the passage as deliberately modelling a highly selfconscious mode of first-personal self-examination (and recall Socrates' remark to Laches, that a third person listening to their conversation would not think they knew what courage was, thereby suggesting this self-conscious mode of 
examination to Laches). ${ }^{50}$ But being a second-best alternative, such solo selfexamination ought to be tested by exposure to scrutiny by others in a joint investigation. ${ }^{51}$ And this is just what Socrates is doing in reporting this conversation he had with himself to another, i.e. to Hippias. ${ }^{52}$ If, as this suggests, in discussion concerning ethical and aesthetic matters dialogue with others is by Plato's lights the authoritative test of what we take ourselves to think, and so authoritative as regards self-knowledge, it appears that Plato advocated firstpersonal plural epistemic authority in the case of self-knowledge: I arrive at the most authoritative claim to know what I think about some matter of inquiry by talking with you and coming to an agreement with you, in accordance with epistemic norms, about what we together think about that object of inquiry. ${ }^{53}$

$5^{\circ} \quad$ Laches 193e. I am grateful to Margaret Hampson for this point.

$5^{1} \quad$ There are clear resonances with the interpretation of cognitive self-knowledge and Platonic self-knowledge proposed here, and the suggestion made by Christopher Gill (1996) that Plato's conception of dialectic exhibits a philosophical outlook he describes as 'objective-participant' throughout the corpus, although especially in the later dialogues. For, on that that view, 'knowledge, if available, is objective, as distinct from subjective or intersubjective' (1996, 284), that is, is aimed at 'discovery of an objectively existing truth' (285) about which it is possible for the inquirers to be in error, and which crucially involves critical dialogue (dialectic) with others. Although I cannot here properly explore or discuss the role of cognitive self-knowledge in dialectic in the dialogues after the early period, and trace the lines of connection and disconnection with the philosophical approach identified by Gill, it is worth noting one divergence between the two views. While Gill claims that 'objective knowledge ... can only be attained by participation in dialectic' $(1996,285)$, it is argued here that dialogue with others is epistemically authoritative, though not the sole means to epistemically respectable (and correct) claims to self-knowledge.

$5^{2}$ Socrates' remark at $298 \mathrm{~b}$ that he would be most ashamed to speak nonsense in front of the son of Sophroniscus (i.e. in front of himself) need not be taken to indicate that he regards himself as the most authoritative judge of either the content or epistemic value of his own thoughts. It could simply indicate that he would be ashamed of himself if he failed to test his own views and beliefs, given a self-conscious adoption of epistemic norms and a grasp of himself as inherently rational, i.e. if he did not strive for cognitive and Platonic self-knowledge as understood here. Similarly, in the Gorgias, after Callicles sulks and Socrates carries on the inquiry out loud with himself, Socrates takes himself to be testing his views in front of the others gathered, telling them and Callicles to object at any point if they disagree with anything Socrates agrees to with himself: $\delta i \varepsilon \mu \mu l \mu \dot{\varepsilon} \nu$ o $v \tau \hat{\omega}$

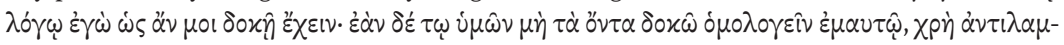

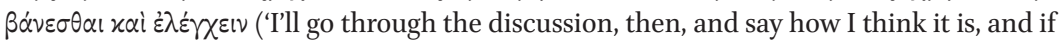
any of you thinks that what I agree to with myself isn't so, you must object and refute me'; Grg. 505e-5o6a, tr. Zeyl; cf. 5o6b-c).

53 The most ideal conversation, then, would be between friends, as in the Crito at $46 \mathrm{~d}, 48 \mathrm{e}$, 49d-e. 
I have argued that Plato's interpretation of the meaning of the Delphic Oracle's command to 'know yourself'-Platonic self-knowledge as I have called ithas at its core correctly ascertaining the content and epistemic status of one's own cognitive states — cognitive self-knowledge — in line with particular epistemic standards or norms. The self-conscious nature of the process of acquiring cognitive self-knowledge exemplified by the elenchus, moreover, invites the agent to adopt the norms as her own and, with reference to them, to develop a pattern of self-conscious scrutiny at a higher-order level of the warrant for, and connection between, various claims at the first-order level, for herself. The method thereby encourages and is able to facilitate the agent's apprehension of herself as an inherently rational being, which, together with cognitive self-knowledge, constitutes Platonic self-knowledge. In matters of moral and aesthetic inquiry, moreover, no matter how strongly justified in this way such higher-order claims are, they are always open to revision in critical discussion with others, in line with these same norms, and therefore subject to the authority of what is agreed in such a dialogue. To this extent, I have argued, Plato endorsed first-personal plural epistemic authority as regards self-knowledge. ${ }^{54}$

\section{References}

Annas, J. (1985). Self-Knowledge in Early Plato. In: D. J. O’Meara, ed., Platonic Investigations. Washington DC, pp. 111-38.

Benson, H. (1995). The Dissolution of the Problem of the Elenchus. Oxford Studies in Ancient Philosophy 13, pp. 45-112.

54 I am grateful to audiences who heard various versions of this paper: the Kinds of Knowledge in Ancient Philosophy 2017 conference at the University of Oslo; the 2018 meeting of the Southern Association of Ancient Philosophy at the University of Cambridge; the University of East Anglia Philosophy Department; Stirling University Philosophy Department; Oklahoma University Philosophy Department; the 42nd Ancient Philosophy Workshop, Texas; and the Berkeley Ancient Philosophy Seminar. For helpful discussion and suggestions I am indebted to Hugh Benson, Sarah Broadie, Timothy Clarke, Christopher Gill, Verity Harte, Mark Kalderon, M. M. McCabe, Lucy O'Brien, Catherine Rowett, Christopher Shields, Nicholas Smith, Ellisif Wasmuth and Paul Woodruff, as well as to the editors and an anonymous reader for the journal. For extensive written comments and discussion, I am particularly grateful to Peter Adamson, Joachim Aufderheide, Elena Cagnoli Fiecconi, Margaret Hampson and Raphael Woolf. 
Benson, H. (2000). Socratic Wisdom: The Model of Knowledge in Plato's Early Dialogues. Oxford.

Boghossian, P. (1989). Content and Self-Knowledge. Philosophical Topics 17: pp. 5-26.

Brickhouse, T. C. and Smith, N. D. (1994). Plato's Socrates. Oxford.

Brunschwig, J. (1973). Sur quelques emplois d' ő $\psi$ เ . In: G. Hookleraar, ed., Zetesis: Album amicorum. Antwerp, pp. 24-39.

Burnyeat, M. (1982). Idealism and Greek Philosophy: What Descartes Saw and Berkeley Missed. Philosophical Review 91, pp. 3-40.

Cassam, Q. (1994). Introduction. In: Q. Cassam, ed., Self-Knowledge. Oxford, pp. 1-19.

Cassam, Q. (2014). Self-knowledge for Humans. Oxford.

Coope, U. (2019). Free to think? Epistemic Authority and Thinking for Oneself. Journal of the British Academy 7, pp. 1-23.

Denyer, N. (2001). Plato: Alcibiades. Cambridge.

Doyle, J. (2012). Socratic Methods. Oxford Studies in Ancient Philosophy 42, pp. 39-75.

Evans, G. (1982). The Varieties of Reference. Oxford.

Ferguson, D. (2019). Self-knowledge in the Eye-Soul Analogy of the Alcibiades. Phronesis 64, pp. 369-91.

Fine, G. (1992). Inquiry in the Meno. In: R. Kraut, ed., The Cambridge Companion to Plato. Cambridge, pp. 200-26.

Gertler, B. (2015). Self-Knowledge. (Revised version.) The Stanford Encyclopedia of Philosophy (Spring 2020 Edition), Edward N. Zalta, ed. https://plato.stanford.edu/ archives/spr2O2o/entries/self-knowledge/.

Giannopoulou, Z. (2015). Self-knowledge in Plato's Theaetetus and Alcibiades I. Proceedings of the Boston Area Colloquium in Ancient Philosophy 30, pp. 73-93.

Gill, C. (1996). Afterward: Dialectic and the Dialogue Form in Late Plato. In: C. Gill and M. M. McCabe, eds., Form and Argument in Late Plato. Oxford, pp. 283-311.

Gill, C. (2007). Self-knowledge in the Alcibiades. In: S. Stern-Gillet and K. Corrigan, eds., Reading Ancient Texts. Leiden/ Boston, pp. 97-112.

Griswald, C. (1983). Self-Knowledge in Plato's Phaedrus. New Haven.

Irwin, T. (1977). Plato's Moral Theory. Oxford.

Jirsa, J. (2009). Authenticity of the Alcibiades I: Some reflections. Listy filologiké 132, pp. 225-44.

Johnson, D. (1999). God as the True Self: Plato's Alcibiades I. Ancient Philosophy 19, pp. 1-19.

Kamtekar, R. (2017). Self-Knowledge in Plato. In: U. Renz, ed., Self-Knowledge: A History. Oxford, pp. 25-43.

Leigh, F. (2020). Kinds of Self-Knowledge in Ancient Thought. In: F. Leigh, ed., Self-Knowledge in Ancient Philosophy. Oxford, pp. 1-50.

Lycan, W. (1988). Tacit Belief. In: R. J. Bogdan, ed., Belief: Form, Content, and Function. Oxford, pp. 61-82. 
McCabe, M. M. (2011). It Goes Deep with Me: Charmides on Knowledge, SelfKnowledge, and Integrity. In: C. Cordner, ed., Philosophy, Ethics, and a Common Humanity. London / New York, pp. 161-80.

McCabe, M. M. (2015). From the Cradle to the Cave: What Happened to Self-knowledge in the Republic? In: M. M. McCabe, Platonic Conversations. Oxford, pp. 208-28. [Reprinted in F. Leigh, ed., Self-Knowledge in Ancient Philosophy. Oxford, pp. 107-29.] Moss, J. and Schwab, W. (2019). The Birth of Belief. Journal of the History of Philosophy 57 , pp. 1-32.

O'Brien, L. (2007). Self-Knowing Agents. Oxford.

Rabbås, Ø. (2004). Definitions and Paradigms: Laches' First Definition. Phronesis 69, pp. $143-68$.

Rappe, S (1996). Self-knowledge and Subjectivity in the Enneads. In: L. Gerson, ed., The Cambridge Companion to Plotinus. Cambridge, pp. 250-74.

Remes, P. (2013). Reason to Care: The Object and Structure of Self-Knowledge in Alcibiades 1. Apeiron 46, pp. 270-301.

Renz, U. (2017), Introduction. In: U. Renz, ed., Self-Knowledge: A History. Oxford, pp. 1-24. Ryle, G. (1949). The Concept of Mind. London.

Sherman, N. (1997). Making a Necessity of Virtue. Cambridge.

Shoemaker, S. (1994). Self Knowledge and 'Inner Sense'. Philosophy and Phenomenological Research 54, pp. 249-314.

Smith, N. D. (2004). Did Plato write the Alcibiades I? Apeiron 37, pp. 93-108.

Tarrant, H (2015). Where Did the Mirror Go? The Text of Plato [?] Alcibiades I 133c1-6. Elenchos 36, pp. 361-72.

Vlastos, G. (1983). The Socratic Elenchus. Oxford Studies in Ancient Philosophy 1, pp. 27-58.

Vlastos, G. (1993). The Socratic Elenchus: Method is All. In: G. Vlastos, Socratic Studies. Cambridge, pp. 1-29.

Woolf, R. (2008). Socratic Authority. Archiv für Geschicte der Philosophie 9o, pp. 1-38. 